\title{
Labour-based Construction Technology for Sustainable Rural Development Infrastructure
}

\author{
Diwat Kumar Shrestha \\ ${ }^{1} \mathrm{PhD}$ Scholar| Department of Engineering| Dr. K.N. Modi University, Newai, Rajasthan, India \\ diwat_shrestha@yahoo.com

\begin{abstract}
Labour-based construction technology is the most important aspect for the development of sustainable rural infrastructure. This study emphasizes on promoting this technology for the overall development and analyzes this aspect in the perspective of rural road bridge sector of Nepal. This technology relates to the environmental, socioeconomic, ownership, livelihood and sustainability aspects of the project area. Infrastructure development is very easy, but sustainability is the key issue which has to be addressed by the infrastructure projects. Labourbased infrastructure is one of the major components to achieve sustainability. Many subcomponents to ensure labour-based aspects are identified and tested in this study.
\end{abstract}

KEYWORDS: Labour-based technology, Road and Bridge Infrastructure, Sustainability

\section{INTRODUCTION}

The term labor-based technology is used to describe a technology that applies a labour/ equipment mix that gives priority to labour, supplementing it with appropriate equipment where necessary for reasons of quality or cost. While producing or maintaining infrastructure to a specified standard in a cost-effective manner, people are employed under fair working conditions. In this respect it is important to distinguish between an optimum and efficient use of labour, as opposed to a maximum, and possibly inefficient use (ILO, 2012).

The South African White Paper on creating an enabling environment for reconstruction, growth and development in the construction Industry expresses a vision for public-sector delivery aimed at optimizing employment opportunities through labour -intensive construction (CIDB, 2005). This can be realized in the delivery of infrastructure through an adoption, of technically and economically feasible. Labour-based methods of construction and manufacturing in labour, utilization of manual tools and light equipment, are preferred to the use of heavy equipment for specific activities; and labour-based technologies which mark there a shift in balance between labour and equipment in the way the work is specified and executed for selected work components.

The improvement of basic infrastructure can be achieved through: 1) creating employment by orienting investments towards employment-intensive public and community infrastructure in both urban and rural areas; 2) constructing, rehabilitating and maintaining infrastructure by using local labour, local resources and local capacities, thereby maximizing employment and income-generation for the poor; 3) providing technical advisory and capacitybuilding services for the planning and implementation of different types of employmentintensive infrastructure (Thawala, 2006, p. 5).

Labour-intensive sectors have several specific advantages. First, it can ensure coordination of three key elements to the growth of labour-intensive sectors in the economy namely, natural resource management, infrastructural development, and basic services to improve human capabilities and productivity of labour. Second, it can raise demand for wage 
goods in the economy, which can be enhanced through labor-intensive industrialization. Finally, it can provide a guarantee of employment and thereby ensure full employment by providing work at the minimum wage, with decent working conditions as well as social protection (Hirway, et.al. 2008, p. 14).

The World Bank in a paper on expanding labour-based methods in road works (1996) has identified six basic delivery/implementing mechanisms, viz.:

I. The force account model ('in house' workforce) whereby a government body hires labour directly (either as individual workers or as worker teams) and provides the necessary supervision, administration and management required to execute the work.

II. The conventional model whereby a conventional contractor hires labour directly and provides the supervision, administration and management required to execute the works.

III. The sub-contracting model whereby a large contractor or firm sub-contracts the portions of the projects that are labour-based to small contractors and assumes overall responsibility for the supervision, administration and management required to execute the works.

IV. The government-run model puts entire onus for all aspects of contractor development, including small contractor administration and payment, supervision, administration, and management ot execute the work. In a nutshell, the whole responsibilities lie with the government agency.

V. The agency model, whereby the responsibilities for all aspects of contractor development including small contractor administration and payment and the overall ownership of the supervision, administration and management are required to execute the works, puts the entire onus on the independent non-profit management agency or with the for-profit consulting firm.

VI. The development team model affixes and divides the responsibility for all aspects of contractor development and the management of the works, to and among the client body (employer), a construction, manager and a materials manager.

Models II and III promote the use of labour-based construction practices amongst established contractors; models IV to VI promote the expansion of such methods among smallscale contractors. In force account operations (Model I), government has direct control over the outcomes of employment-intensive projects and is at risk for any failure to achieve programme objectives. The government's control over the works in all the other models is, however, diminished. Its risk of failure in these models is reduced, the extent of which is dependent upon the model which is selected. The total project costs of each of the models which involve the private sector is, in turn, directly related to how the risk is managed and assigned to the contracting parties and the nature and complexity of the work involved.

\section{OBJECTIVE OF STUDY}

The objective of this study is the identification of labour-based bridge construction technology practiced in Nepal, with the criteria and elements used to access the technology, by: exploring and identifying labour-based technology in bridge construction in Nepal.

Identifying criteria and elements used to access the labour-based bridge construction technology. Identifying the labour-based bridge construction technology initiatives in the global contest. The alternative hypothesis used in this study is labour-based construction technology, is practiced in Nepal, especially in road and bridge construction. Labour-based construction technology is the successful technology to promote sustainability in Nepal. But due to many implications to the implementers, they may not be interested in implementing this technology. Benefits of projects to the labours, application of labours in the bridge projects, the role of 
labours in achieving quality work and human resources development at the local level are the parts of the study.

\section{METHODOLOGY}

Only by the use of appropriate methodologies and methods of research, applied with rigour, can the body of knowledge for construction be established and advanced with confidence (Fellow \& Liu, 1997). Therefore, each element in the research - the theoretical and conceptual framework guiding the study, sample characteristics, data collection approaches and procedures, and the analysis and interpretation of data - is equally important in the overall plan for the conduct of the study. A well-organized research methodology that follows logically form the specific aims and demonstrates the integration of each these aims throughout the research plan is a crucial component of successful application.

The methodology used for this study is questionnaire survey. The main objective of the questionnaire survey is to address the critical sustainability approaches by identifying the best practices in the real projects in Nepal, which covers the projects of snowy mountain (Himali) region, mountain region and plain (Tarai) region. Almost all data are primarily quantitative as the research, at this phase, has sought to understand the measures taken and processes involved at the project level to address labour-based technology.

The fact that the desired investigation has required a close understanding of what has been happening at the project level, and had to rely on the interpretation of data (by collecting information from, and experiencing, the project environment) has made this investigation not only suited to a quantitative approach, which requires structured and standardized quantities. Furthermore, the identification of good practice at the project requires the more mature lines of enquiry provided by the qualitative approach. A questionnaire survey is one of the most cost effective ways to involve a large number of people in the process in order to achieve better results, as recommended by McQueen and Knussen (2002). Pilot survey and Cronbach's Alpha test of questionnaire have also been done during this study.

\section{DATA ANALYSIS AND PRESENTATION}

Practice of labour-based technology in Nepal especially in the road bridge sector, and the criterion and indicators to assess the technology is the main target area of the study and the data analysis is also focused on it.

The questionnaire survey was conducted in 3 regions of Nepal (Himal, Hill and Tarai) with 5 rural bridge projects. Eastern, Central and Western part of Nepal were also covered by the survey. Table 1 is about the overlook of the survey area of Nepal. The study has covered all regions and locations of the nation, so that the survey may become reliable and credible.

Table 1. Questionnaire survey locations and respective bridge projects

\begin{tabular}{|c|c|c|c|c|c|}
\hline S.N. & Districts & Region & Name of the Project & Area & Remarks \\
\hline 1 & Bankey & Tarai & Duduwa Nala Bridge & Western & \\
\hline 2 & Rasuwa & \multirow{2}{*}{ Himali } & Bhote Koshi Bridge & \multirow{2}{*}{ Central } & \\
\hline 3 & Solukhumbu & & Solu Khola Bridge & & \\
\hline 4 & Illam & \multirow{2}{*}{ Mountain } & Karphok Khola Bridge & \multirow{2}{*}{ Eastern } & \\
\hline 5 & Panchthar & & Nibu (Siwa) Khola Bridge & & \\
\hline
\end{tabular}


JOURNAL OF ADVANCED ACADEMIC RESEARCH (JAAR)

Basic factual data were collected relating to the respondents personally with the clients and users of bridges. This data are presented in this section. The size of the response across available response categories is indicated in both percentage $(\%)$ and raw numeric terms.

Table 2 indicates the most respondents $(85 \%)$ are from users' side, $15 \%$ are from clients. The percentage of male and female respondents is $71 \%$ and $29 \%$ respectively. At the regional basis the respondent percentage of Himal, Hill and Tarai are $27 \%, 33 \%$ and $40 \%$ respectively. The total number of respondents was 299. Among them 81 from Himal, 100 from Mountain and 118 from Tarai and 44 clients and 255 users took part in this study. Opinions and views obtained through this survey are regarded as important and reliable. Majority of respondents had reasonable experience in respective bridge construction, which were further shows that respondents are sufficiently experienced enough to provide data which are credible.

Table 2: Number of respondents according to their type and regional basis

\begin{tabular}{|c|c|c|c|c|c|c|c|}
\hline \multirow{3}{*}{ Region } & \multicolumn{4}{|c|}{ Respondent Type } & \multirow{2}{*}{\multicolumn{3}{|c|}{ Total (299) }} \\
\hline & \multicolumn{2}{|c|}{ Clients (44) } & \multicolumn{2}{|c|}{ Users (255) } & & & \\
\hline & $\mathrm{M}$ & $\mathrm{F}$ & $\mathrm{M}$ & $\mathrm{F}$ & $\mathrm{M}$ & $\mathrm{F}$ & $\%$ \\
\hline Himali & 5 & 1 & 48 & 27 & 53 & 28 & 27 \\
\hline Mountain & 19 & - & 65 & 16 & 84 & 16 & 33 \\
\hline Tarai & 16 & 3 & 59 & 40 & 75 & 43 & 40 \\
\hline Total & 40 & 4 & 172 & 83 & 212 & 87 & 100 \\
\hline$\%$ & \multicolumn{2}{|l|}{15} & \multicolumn{2}{|l|}{85} & 71 & 29 & \\
\hline
\end{tabular}

Field

Survey,2013

\begin{tabular}{|l|l|l|l|l|}
\hline \multirow{2}{*}{ Respondent Type } & \multicolumn{2}{|l|}{ Region } & \multirow{2}{*}{ Total } \\
\cline { 2 - 4 } & Himal & Mountain & Tarai & 44 \\
\hline Client & 6 & 19 & 19 & 255 \\
\hline Users & 75 & 81 & 99 & 299 \\
\hline Total & 81 & 100 & 118 & 100 \\
\hline$\%$ & 27 & 33 & 40 & \\
\hline
\end{tabular}

Field Survey, 2013

The survey was conducted in five districts which represent all the 3 geographical regions of Nepal (Table 3). In tarai region the district was Bankey, in hilly region the districts were Panchthar and Illam, and in himali region the districts were Rasuwa and Solukhumbhu. The districts cover Eastern, Central and Western part of Nepal. The female participation (29\%) is encouraged tarai, hill and himali participation $40 \%, 33 \%$ and $27 \%$ is according to the population distribution. The distribution of sample is homogeneous and representative so that the outputs becomes reliable.

Table 3: Distribution of respondents by their district, gender and project area

\begin{tabular}{|l|l|l|l|l|l|l|l|l|}
\hline \multirow{2}{*}{ District } & \multicolumn{2}{l|}{ Himal (81) } & \multicolumn{2}{l|}{ Hill (100) } & \multicolumn{2}{l|}{ Tarai (118) } & \multicolumn{2}{l|}{ Total (299) } \\
\cline { 2 - 10 } & M & F & M & F & M & F & M & F \\
\hline Banke & - & - & - & - & 75 & 43 & 75 & 43 \\
\hline Rasuwa & 30 & 18 & - & - & - & - & 30 & 18 \\
\hline Solukhumbu & 23 & 10 & - & - & - & - & 23 & 10 \\
\hline Panchthar & - & - & 43 & 8 & - & - & 43 & 8 \\
\hline Ilam & - & - & 41 & 8 & - & - & 41 & 8 \\
\hline
\end{tabular}


ISSN: 2362-1303 (Paper) | eISSN: 2362-1311(Online)

JOURNAL OF ADVANCED ACADEMIC RESEARCH (JAAR)

July 2014

\begin{tabular}{|l|l|l|l|l|l|l|l|l|}
\hline Total & 53 & 28 & 84 & 16 & 75 & 43 & 212 & 87 \\
\hline$\%$ & 27 & 33 & & 40 & & 71 & 29 \\
\hline
\end{tabular}

Field Survey, 2013

The purpose of this survey is to investigate the practice of labour-based construction technology in Nepal and find the perspectives of clients and users towards labour-based construction technology. The responding clients and users indicated that they were aware of the labou-based construction technology. Many components were measured to find out the use of labour-based construction technology in the rural infrastructure development: Ownership feeling of community towards project (Table 4), relationship between the local users and the project (Table 8), relationship between government departments/offices and the project (Table 9), relationship between technicians/ experts in the project (Table 10), relationship between local and regional communities (Table 11) and relationship between users, residents and owner in the bridge construction (Table 12) were highly significant.

Table 4 shows that $71 \%$ of the participants agreed upon the communities' ownership feeling towards the project while $22 \%$ disagreed. This means that the project was able to get the support of the communities and they were feeling that the bridges were their own property.

Table 8 to 12 denotes the relationships between different stakeholders and the projects. In Table $8,71 \%$ of the participants convinced in the good relationship between the local users and the project while $22 \%$ are not convince. Seventy Six (76) percent agreed about the good relationship between government department/offices and the project but $18 \%$ disagreed, in Table 9. Similarly, $71 \%$ of the respondents are in favor of good relationship between technician/expert in the project, but $21 \%$ are not in favor (Table 10). According to Table 11, $73 \%$ agree that the relationship between local and regional communities is good and 19\% respondents do not agree with this. Table 12 shows that $76 \%$ respondents are agreed that relationship between users; residents and owner are good while $21 \%$ disagree.

So far as the views of the data on relationships between different stakeholders regarding the bridge project are concerned, they are highly significant, and the relationships play a vital role for the success of these types of projects. These relationships are directly proportionate with give and take between stakeholders and project give and take in terms of employment, social values, income generation, business promotion, industrial development etc. To promote these things the project has to be involved with local human resources and promote labour-based construction technology.

Other key components for labour-based construction are qualified and experienced contractor selection, project management system, working procedures and implementation of labour law, role of social organizations to protect cultural and natural heritage. Labour-based construction emphasizes labour more than machinery equipment and explosives. Maximum uses of the labours, quality of skilled local manpower and quality tests of the jobs are the paramount importance. All the components have been analyzed thoroughly and the data are presented accordingly as follows. Table 5 denotes, $86 \%$ respondents are in favor of qualified and experienced contractor selection while only $10 \%$ are not in favor of it. The quality of work depends on the quality of contractor, so the data shows that the quality of project is very good.

Project management system plays the main role in making the project successful. Seventy seven (77) percent respondents are satisfied where as $17 \%$ are unsatisfied about the management of projects (Table 6). It is shown that an overall project management aspect seems good.

According to Table 7, 77\% agrees that working procedures and implementations of labour law have been very good in the projects while $18 \%$ disagrees. The working procedures 
and implementations of labour law are the main components to establish labour-based construction technology in the projects.

Role of social organizations to protect cultural and natural heritage is another necessary component to promote the use of local labours in the projects. About it, $69 \%$ is in favor while $22 \%$ is not in favor (Table 13).

Table 14 denotes that $70 \%$ of the respondents are convinced that the projects emphasize labours more than machinery equipment and explosives while $25 \%$ remained unconvinced. To promote labour-based construction technology, minimization of machinery equipment and explosives must be undertaken. The data show the satisfactory input of labours more than machinery equipment and explosives.

Eighty-one (81) percent of the respondents are convinced that maximum use of the labour force is made in the construction of projects while only $11 \%$ are not convinced about it (Table 15). Clearly, the data shows that the projects have been positive towards labour-based construction technology.

Quality of skilled local manpower is another aspect to introduce the labour-based construction technology. If the quality manpower is not available locally then the use of machinery equipment will be of course increased, which means labour-based construction technology will no more exist to no more. Table 16 denotes that $81 \%$ of the respondents are convinced that the quality of skilled local manpower is available while $13 \%$ were not convinced about it. What is this means that quality of skilled local manpower is good.

A quality test of the jobs of bridge construction is the key component to make the skilled manpower more qualitative. Quality test is essential to make the project durable and effective. This is directly proportional to the quality enhancement of local manpower or labour-based construction. Table 17, shows that $76 \%$ of the respondents are agreed that the quality test procedures is satisfactory and only $16 \%$ disagree about it. The data shows that quality test procedures are satisfactory in the projects.

Table 4: Ownership feeling of community towards project.

\begin{tabular}{|l|l|l|l|l|l|l|l|l|}
\hline Group & \multicolumn{4}{|l|}{ Scale values } & \multicolumn{1}{l|}{ Total } & Weighted & Mean \\
Responses & Value & Weight \\
\hline Clients & 1 & 2 & 3 & 4 & 5 & 200 & 4.54 \\
\hline Users & 0 & 1 & 2 & 13 & 28 & 44 & 200 & 3.76 \\
\hline Total & 32 & 33 & 19 & 51 & 120 & 255 & 959 & 3.87 \\
\hline$\%$ & 32 & 34 & 21 & 64 & 148 & 299 & 1159 & \\
\hline
\end{tabular}

Field Survey, 2013

Table 1: Selection of qualified and experienced contractor

\begin{tabular}{|l|l|l|l|l|l|l|l|l|}
\hline \multirow{2}{*}{ Group } & \multicolumn{3}{|l|}{ Scale values } & $\begin{array}{l}\text { Total } \\
\text { Responses }\end{array}$ & $\begin{array}{l}\text { Weighted } \\
\text { Value }\end{array}$ & $\begin{array}{l}\text { Mean } \\
\text { Weight }\end{array}$ \\
\cline { 2 - 8 } & 1 & 2 & 3 & 4 & 5 & & 194 & 4.4 \\
\hline Clients & 1 & 2 & 1 & 14 & 26 & 44 & 1092 & 4.28 \\
\hline Users & 7 & 18 & 12 & 77 & 141 & 255 & 1286 & 4.3 \\
\hline Total & 8 & 20 & 13 & 91 & 167 & 299 & & \\
\hline$\%$ & 3 & 7 & 4 & 30 & 56 & 100 & & \\
\hline
\end{tabular}

Field Survey, 2013

Table 6: Management system of the project

\begin{tabular}{|l|l|l|l|l|l|l|l|l|}
\hline \multirow{2}{*}{ Group } & \multicolumn{4}{|l|}{ Scale values } & Total & Weighted & Mean \\
& 1 & 2 & 3 & 4 & 5 & Responses & Value & Weight \\
\hline
\end{tabular}


ISSN: 2362-1303 (Paper) | eISSN: 2362-1311(Online)

JOURNAL OF ADVANCED ACADEMIC RESEARCH (JAAR)

July 2014

\begin{tabular}{|l|l|l|l|l|l|l|l|l|}
\hline Clients & 1 & 11 & 3 & 12 & 17 & 44 & 165 & 3.75 \\
\hline Users & 5 & 32 & 16 & 75 & 127 & 255 & 1052 & 4.12 \\
\hline Total & 6 & 43 & 19 & 87 & 144 & 299 & 1217 & 4.07 \\
\hline$\%$ & 2 & 15 & 6 & 29 & 48 & 100 & & \\
\hline
\end{tabular}

Field Survey, 2013

Table 7: Construction working procedures and the labour law

\begin{tabular}{|l|l|l|l|l|l|l|l|l|}
\hline \multirow{2}{*}{ Group } & \multicolumn{3}{|l|}{ Scale values } & $\begin{array}{l}\text { Total } \\
\text { Responses }\end{array}$ & $\begin{array}{l}\text { Weighted } \\
\text { Value }\end{array}$ & Mean Weight \\
\cline { 2 - 7 } & 1 & 2 & 3 & 4 & 5 & & \\
\hline Clients & 0 & 4 & 5 & 19 & 16 & 44 & 179 & 4.06 \\
\hline Users & 11 & 39 & 11 & 63 & 131 & 255 & 1029 & 4.03 \\
\hline Total & 11 & 43 & 16 & 82 & 147 & 299 & 1208 & 4.04 \\
\hline$\%$ & 4 & 14 & 5 & 28 & 49 & 100 & & \\
\hline
\end{tabular}

Field Survey, 2013

Table 8: Relationship between the local users and the project

\begin{tabular}{|l|l|l|l|l|l|l|l|l|}
\hline \multirow{2}{*}{ Group } & \multicolumn{3}{|l|}{ Scale values } & $\begin{array}{l}\text { Total } \\
\text { Responses }\end{array}$ & $\begin{array}{l}\text { Weighted } \\
\text { Value }\end{array}$ & $\begin{array}{l}\text { Mean } \\
\text { Weight }\end{array}$ \\
\cline { 2 - 10 } & 1 & 2 & 3 & 4 & 5 & & & \\
\hline Clients & 0 & 6 & 0 & 16 & 22 & 44 & 186 & 4.22 \\
\hline Users & 17 & 41 & 22 & 70 & 105 & 255 & 970 & 3.8 \\
\hline Total & 17 & 47 & 22 & 86 & 127 & 299 & 1157 & 3.86 \\
\hline$\%$ & 6 & 16 & 7 & 29 & 42 & 100 & & \\
\hline
\end{tabular}

Field Survey, 2013

Table 2: Relationship between government department/offices and the project

\begin{tabular}{|c|c|c|c|c|c|c|c|c|}
\hline \multirow{2}{*}{ Group } & \multicolumn{5}{|c|}{ Scale values } & \multirow{2}{*}{$\begin{array}{l}\text { Total } \\
\text { Responses }\end{array}$} & \multirow{2}{*}{$\begin{array}{l}\text { Weighted } \\
\text { Value }\end{array}$} & \multirow{2}{*}{$\begin{array}{l}\text { Mean } \\
\text { Weight }\end{array}$} \\
\hline & 1 & 2 & 3 & 4 & 5 & & & \\
\hline Clients & 1 & 5 & 1 & 13 & 24 & 44 & 186 & 4.22 \\
\hline Users & 13 & 34 & 18 & 77 & 113 & 255 & 1008 & 3.95 \\
\hline Total & 14 & 39 & 19 & 90 & 137 & 299 & 1194 & 3.99 \\
\hline$\%$ & 5 & 13 & 6 & 30 & 46 & 100 & & \\
\hline
\end{tabular}

Field Survey, 2013

Table 10: Relationship between technician/experts in the project

\begin{tabular}{|l|l|l|l|l|l|l|l|l|}
\hline \multirow{2}{*}{ Group } & \multicolumn{3}{|l|}{ Scale values } & $\begin{array}{l}\text { Total } \\
\text { Responses }\end{array}$ & $\begin{array}{l}\text { Weighted } \\
\text { Value }\end{array}$ & $\begin{array}{l}\text { Mean } \\
\text { Weight }\end{array}$ \\
\cline { 2 - 10 } & 1 & 2 & 3 & 4 & 5 & & & \\
\hline Clients & 0 & 5 & 2 & 13 & 24 & 44 & 175 & 3.97 \\
\hline Users & 29 & 28 & 23 & 81 & 94 & 255 & 948 & 3.71 \\
\hline Total & 29 & 33 & 25 & 94 & 118 & 299 & 1136 & 3.79 \\
\hline$\%$ & 10 & 11 & 8 & 31 & 40 & 100 & & \\
\hline
\end{tabular}

Field Survey, 2013

Table 11: Relationship between local and regional communities

\begin{tabular}{|l|l|l|l|l|l|l|l|l|}
\hline \multirow{2}{*}{ Group } & \multicolumn{4}{|l|}{ Scale values } & $\begin{array}{l}\text { Total } \\
\text { Responses }\end{array}$ & $\begin{array}{l}\text { Weighted } \\
\text { Value }\end{array}$ & $\begin{array}{l}\text { Mean } \\
\text { Weight }\end{array}$ \\
\cline { 2 - 10 } & 1 & 2 & 3 & 4 & 5 & 44 & 179 & 4.06 \\
\hline Clients & 0 & 5 & 4 & 18 & 17 & 44 & 977 & 3.83 \\
\hline Users & 12 & 41 & 20 & 87 & 95 & 255 & 977 \\
\hline
\end{tabular}


ISSN: 2362-1303 (Paper) | eISSN: 2362-1311(Online)

JOURNAL OF ADVANCED ACADEMIC RESEARCH (JAAR)

July 2014

\begin{tabular}{|l|l|l|l|l|l|l|l|l|}
\hline Total & 12 & 46 & 24 & 105 & 112 & 299 & 1156 & 3.86 \\
\hline$\%$ & 4 & 15 & 8 & 35 & 38 & 100 & & \\
\hline
\end{tabular}

Field Survey, 2013

Table 123: Relationship between users, residents and owner in the bridge construction

\begin{tabular}{|l|l|l|l|l|l|l|l|l|}
\hline \multirow{2}{*}{ Group } & \multicolumn{3}{|l|}{ Scale values } & $\begin{array}{l}\text { Total } \\
\text { Responses }\end{array}$ & $\begin{array}{l}\text { Weighted } \\
\text { Value }\end{array}$ & $\begin{array}{l}\text { Mean } \\
\text { Weight }\end{array}$ \\
\cline { 2 - 9 } & 1 & 2 & 3 & 4 & 5 & & & \\
\hline Clients & 0 & 3 & 1 & 18 & 22 & 44 & 191 & 4.34 \\
\hline Users & 12 & 46 & 9 & 81 & 107 & 255 & 982 & 3.85 \\
\hline Total & 12 & 49 & 10 & 99 & 129 & 299 & 1181 & 3.94 \\
\hline$\%$ & 4 & 17 & 3 & 33 & 43 & 100 & & \\
\hline
\end{tabular}

Field Survey, 2013

Table 13: Role of social organizations to protect cultural and natural heritage

\begin{tabular}{|l|l|l|l|l|l|l|l|l|}
\hline \multirow{2}{*}{ Group } & \multicolumn{4}{|l|}{ Scale values } & $\begin{array}{l}\text { Total } \\
\text { Responses }\end{array}$ & $\begin{array}{l}\text { Weighted } \\
\text { Value }\end{array}$ & Mean \\
\cline { 2 - 8 } & 1 & 2 & 3 & 4 & 5 & Weight \\
\hline Clients & 0 & 8 & 3 & 16 & 17 & 44 & 174 & 3.95 \\
\hline Users & 16 & 43 & 25 & 85 & 86 & 255 & 947 & 3.71 \\
\hline Total & 16 & 51 & 28 & 101 & 103 & 299 & 1121 & 3.74 \\
\hline$\%$ & 5 & 17 & 9 & 34 & 35 & 100 & & \\
\hline
\end{tabular}

Field Survey, 2013

Table 14: Emphasize labours than Machinery equipment and explosives

\begin{tabular}{|l|l|l|l|l|l|l|l|l|}
\hline \multirow{2}{*}{ Group } & \multicolumn{4}{|l|}{ Scale values } & $\begin{array}{l}\text { Total } \\
\text { Responses }\end{array}$ & $\begin{array}{l}\text { Weighted } \\
\text { Value }\end{array}$ & Mean Weight \\
\cline { 2 - 8 } & 1 & 2 & 3 & 4 & 5 & 44 & 183 & 4.15 \\
\hline Clients & 2 & 2 & 2 & 19 & 19 & 44 & 972 & 3.81 \\
\hline Users & 30 & 39 & 12 & 42 & 132 & 255 & 1155 & 3.86 \\
\hline Total & 32 & 41 & 14 & 61 & 151 & 299 & & \\
\hline$\%$ & 11 & 14 & 5 & 20 & 50 & 100 & & \\
\hline & & & & & & & & \\
\hline
\end{tabular}

Field Survey, 2013

Table 15: Maximum uses of labours in the bridge construction

\begin{tabular}{|l|l|l|l|l|l|l|l|l|}
\hline \multirow{2}{*}{ Group } & \multicolumn{3}{|l|}{ Scale values } & $\begin{array}{l}\text { Total } \\
\text { Responses }\end{array}$ & $\begin{array}{l}\text { Weighted } \\
\text { Value }\end{array}$ & $\begin{array}{l}\text { Mean } \\
\text { Weight }\end{array}$ \\
\cline { 2 - 9 } Clients & 1 & 2 & 3 & 4 & 5 & 44 & 180 & 4.09 \\
\hline Users & 2 & 5 & 1 & 15 & 21 & 44 & 1079 & 4.23 \\
\hline Total & 8 & 20 & 22 & 60 & 145 & 255 & 1259 & 4.21 \\
\hline$\%$ & 10 & 25 & 23 & 75 & 166 & 299 & & \\
\hline
\end{tabular}

Field Survey, 2013

Table 164: Quality of skilled local manpower in the bridge construction area

\begin{tabular}{|l|l|l|l|l|l|l|l|l|}
\hline \multirow{2}{*}{ Group } & \multicolumn{3}{|l|}{ Scale values } & \multicolumn{2}{l}{$\begin{array}{l}\text { Total } \\
\text { Responses }\end{array}$} & $\begin{array}{l}\text { Weighted } \\
\text { Value }\end{array}$ & $\begin{array}{l}\text { Mean } \\
\text { Weight }\end{array}$ \\
\cline { 2 - 6 } Clients & 1 & 2 & 3 & 4 & 5 & & 169 & 3.84 \\
\hline Users & 2 & 7 & 3 & 16 & 16 & 44 & 1083 & 4.24 \\
\hline Total & 7 & 25 & 15 & 67 & 143 & 255 & 1252 & 4.18 \\
\hline$\%$ & 2 & 11 & 6 & 28 & 53 & 100 & & \\
\hline
\end{tabular}

Field Survey, 2013 
ISSN: 2362-1303 (Paper) | eISSN: 2362-1311(Online)

JOURNAL OF ADVANCED ACADEMIC RESEARCH (JAAR)

July 2014

Table 175: Quality tests of the jobs of bridge construction

\begin{tabular}{|l|l|l|l|l|l|l|l|l|}
\hline \multirow{2}{*}{ Group } & \multicolumn{4}{|l|}{ Scale values } & $\begin{array}{l}\text { Total } \\
\text { Responses }\end{array}$ & $\begin{array}{l}\text { Weighted } \\
\text { Value }\end{array}$ & $\begin{array}{l}\text { Mean } \\
\text { Weight }\end{array}$ \\
\cline { 2 - 6 } & 1 & 2 & 3 & 4 & 5 & & 191 & 4.34 \\
\hline Clients & 1 & 3 & 5 & 6 & 29 & 44 & 1027 & 4.02 \\
\hline Users & 12 & 33 & 19 & 63 & 128 & 255 & 1218 & 4.07 \\
\hline Total & 13 & 36 & 24 & 69 & 157 & 299 & & \\
\hline$\%$ & 4 & 12 & 8 & 23 & 53 & 100 & & \\
\hline
\end{tabular}

Field Survey, 2013

Test of significance for the practice of labour-based construction technology in Nepal was done with two kinds of populations who agree with the proposed approaches. Based on the populations' percentage that agrees with the approaches $x^{2}$ value, $\mathrm{p}$ value and conclusions with significance and insignificance have been calculated using SPSS. Individual and overall test of significance have been made accordingly. Regarding the individual test, Table 4, 8, 9, 10, 11 and 12 show high significance because whether the $\mathrm{p}$ value is less than 0.05 . And regarding other remaining 8 individual tests, in the remaining tables, the $p$ value is greater than 0.05 , so that it seems these are insignificant.

Overall significance test regarding the practice of labour-based construction technology in Nepal (Table 18) has been done accordingly. Mean, standard deviation, $t$ value and $p$ value have been calculated using SPSS and the $p$ value has been found to be greater than 0.05 . Thus, it is proved that the alternative hypothesis "Labour-based construction technology is practiced in Nepal, especially in road and bridge construction" is insignificant. The practice of labour-based construction technology is insignificant in the opinions of clients and users. They are really not committed to introduce labour-based construction technology in road and bridge constructions.

Table 18: Overall significance test regarding practice of labour-based construction technology in Nepal.

\begin{tabular}{|l|l|l|l|l|l|}
\hline Group & Means & $\begin{array}{l}\text { Std. } \\
\text { Deviation }\end{array}$ & $\mathrm{t}$ Value & $\begin{array}{l}p \\
\text { Value }\end{array}$ & $\begin{array}{l}\text { Sig if } \\
p<0.05\end{array}$ \\
\hline Client & 58.295 & 10.518 & Equal variances assumed 1.739 & 0.083 & Insignificant \\
\cline { 1 - 3 } User & 55.423 & 10.045 & Equal variances assumed 1.684 & 0.098 & \\
\hline
\end{tabular}

Field Survey, 2013

\section{CONCLUSION}

In an effort to establish sustainability criteria and indicators suitable for Nepalese road bridge infrastructure projects, a thorough review of existing sustainability rating tools and schemes was conducted at the beginning of the research. Several established sustainability assessment tools that are being adopted in the built environment or infrastructure in Nepal and overseas were examined.

The improvement of basic infrastructure can be achieved by labour-based technology by: 1) creating employment by orienting investments towards employment-intensive public and community infrastructure in both urban and rural areas; 2)constructing, rehabilitating and maintaining infrastructure using local labour, local resources and local capacities, thereby maximizing employment and income-generation for the poor; 3)providing technical advisory and capacity-building services for the planning and implementation of different types of employment-intensive infrastructure (Thawala, 2006, p. 5). 
Labour-based technology was the main target and in implementation also it was followed through answering the research question. The objective, which was identification of labour-based bridge construction technology practiced in Nepal, with the criteria and elements used to access the technology, was achieved.

\section{BIBLIOGRAPHY}

CIDB. (2005). An overview of labour-based technologies and methods in employment-intensive works. Brooklyn Square,: Construction Industry Development Board.

Fellow, R., \& Liu, A. (1997). "Research Methods for Construction". Blackwill Science Limited, U. K.

Hirway, I., Saluja, M. R., \& Yadav, B. (2008). The impact of public employment guarantee strategies on gender equality and pro-poor economic development. p. 110.

ILO. (2012). Employment Intensive Investment Programme. International Labour Organization, Morillons, Genève, Switzerland.

MCqueen, R. A., \& Knussen, C. (2002). Research Methods for Social Science: A Practical Introduction. Harlow, Prentice Hall.

Thawala, W. D. (2006). Urban Renewal through Labour-Intensive Construction Technology in South Africa: Problems and Potentials. 8 (4), p. 9.

WB. (1996). Expanding labour-based methods in road works. World bank. 